\author{
Zbigniew Zioło \\ Zakład Przedsiębiorczości i Gospodarki Przestrzennej \\ Instytut Geografii \\ Akademia Pedagogiczna w Krakowie
}

\title{
Rola przedsiębiorczości w podnoszeniu konkurencyjności społeczeństwa i gospodarki
}

Postępujące procesy rozwoju cywilizacyjnego w coraz poważniejszym stopniu wpływają na umiędzynarodowienie produkcji, działalności usługowej oraz działalności instytucji, głównie finansowych. Prowadzą do pogłębiania istniejących i poszukiwania nowych rynków zbytu, rozszerzając $\mathrm{w}$ ten sposób różnego typu powiązania przestrzenne. Kształtujący się światowy, krajowy i regionalny rynek jest miejscem konfrontacji różnych produktów, o których wyborze decydują odbiorcy. Podejmując decyzje, odbiorcy kierują się różnymi kryteriami, wynikającymi m.in. z: zasobów finansowych, upodobań, tradycji, zmieniających się gustów i potrzeb poszczególnych osób czy określonych grup społecznych, a także potrzeb różnorodnych podmiotów gospodarczych i instytucji, uznawanych wartości kulturowych czy często zmieniającej się sytuacji gospodarczej i społecznej. Szczególnie wyraźnie jest to widoczne w zachowaniach na rynku Stanów Zjednoczonych dwóch wiodących koncernów samochodowych: General Motors Corporation (GM) i Toyoty. We wrześniu $2005 \mathrm{r}$. w porównaniu z sierpniem sprzedaż Toyoty w Stanach Zjednoczonych zwiększyła się o 10\%, sprzedaż GM spadła o 24\%, a sprzedaż Forda spadła o 20\% ${ }^{1}$. W konsekwencji japoński koncern nie ma trudności finansowych i pozbył się nadmiernych zapasów, natomiast GM znalazł się w poważnym kryzysie wynikającym z zakłóceń płynności finansowej. Wobec rosnącej ceny paliw, dochodzącej do 3 dolarów za galon $(3,8$ 1), Amerykanie ,polubili” samochody japońskie, zużywające prawie o połowę mniej paliwa. Wpłynęło to również na znaczny wzrost rynkowej wartości koncernu Toyota - do $168 \mathrm{mld}^{2}$ dolarów (czyli o 10 mld dolarów). Osiagnięcie tego sukcesu wymagało przyjęcia długoletniej strategii rozwoju, kładącej nacisk na niezawodność pojazdu oraz spełnianie przez niego wymogów ekologicznych i ekonomicznych. Było to możliwe dzięki zaostrzeniu systemu kontroli jakości oraz poniesieniu znacznych wydatków $\left(5,7\right.$ mld dolarów $\left.^{3}\right)$ na badania i rozwój, oraz pracy odpowiednio przygotowanych kadr, które:

\footnotetext{
${ }^{1}$ D. Walewska, Amerykanie zostali za Toyota, Rzeczpospolita, 5.10.2005 r.

${ }^{2}$ Dla porównania, PKB Polski w 2003 r. wyniósł 209,6 mld dolarów.

${ }^{3}$ Dla porównania, w $2003 \mathrm{r}$. wydatki z budżetu państwa na naukę wyniosły $207 \mathrm{mln} \mathrm{zł}, \mathrm{tj} .1,4 \%$ ogólnych wydatków, czyli 0,3\% PKB, a na szkolnictwo wyższe - $701 \mathrm{mln}$ zł, tj 3,7\% wydatków ogólnych, czyli 0,9\% PKB (za: Rocznik Statystyczny Rzeczypospolitej Polskiej 2004, GUS, Warszawa 2004, s. 622). Według kursu miesięcznego ogłoszonego 23.09.2005 r. (za: „Gazeta Wyborcza”, 26.09.2005 r.), wynoszącego 3,2931 zł za 1 dolara, nakłady na naukę w tym roku wyniosły 0,062 mld dolarów, a na szkolnictwo wyższe 0,213 mld dolarów.
} 
- na podstawie wielu studiów diagnostycznych zbudowały strategię rozwoju koncernu wybiegającą daleko w przyszłość, w której uwzględniono przewidywane tendencje rozwoju produktu, stopień jego konkurencyjności na rynku, zmieniającą się sytuację na rynku paliw oraz sytuację społeczno-gospodarczą;

- wytyczyły kierunki prac badawczych i wdrożeniowych związane z poszukiwaniem coraz to nowych materiałów;

- systematycznie doskonalą prace projektowe nad wyrobami;

- stale doskonalą i wdrażają nowoczesne procesy technologiczne;

- uzyskują środki finansowe na coraz wydajniejsze wyposażenie techniczne stanowisk pracy;

- zostały odpowiednio przygotowane do podejmowania decyzji i zarządzania nowymi organizacjami produkcji i jej obsługi.

Można więc przyjąć, że w tym procesie podstawową rolę odegrał przedsiębiorczy człowiek, a technika była zespołem narzędzi, którymi się posługiwał. Zespolenie funkcjonalne odpowiednio przygotowanych kadr pracowniczych i będącej na odpowiednim poziomie techniki oraz współpracujących z nimi różnorodnych instytucji umożliwia oferowanie nowych produktów, co dzięki opanowywaniu rynków prowadzi do wzrostu gospodarczego i w konsekwencji umożliwia rozwój społeczeństwa. Wynikają stąd ścisłe relacje między przedsiębiorczością a tempem wzrostu gospodarki, które wpływają na przyspieszanie rozwoju społecznego. Można więc przyjąć tezę, że szczególną rolę odgrywa tu odpowiednio przygotowany, przedsiębiorczy człowiek, który uczestniczy w procesie wzrostu produkcji i rozwoju gospodarczym, a rozumiejąc mechanizmy tych procesów przyczynia się do racjonalnego rozwoju społeczeństwa.

Poszczególne osoby funkcjonujące w strukturze społeczeństwa odznaczają się różnymi zdolnościami (talentami), dzięki którym mogą spełniać odpowiednie role w strukturze społecznej. Przyjmujemy, że w zbiorowości społecznej te zdolności nawiązują do rozkładu normalnego. Wynikają one z indywidualnych cech poszczególnych osób, które umożliwiają im odpowiedni rozwój i przygotowanie do wykonywania określonych funkcji w rozwijającym się społeczeństwie. Podobnie jak szczególne predyspozycje fizyczne i intelektualne mają sportowcy, kompozytorzy, literaci czy poszczególne grupy pracownicze, tak samo powinny je mieć osoby związane z zarządzaniem i organizacją w zakresie rozwoju działalności produkcyjnej, gospodarczej czy społecznej. Należy podkreślić złożoność tego zadania, związanego nie tylko z zarządzaniem w przedsiębiorstwach i różnego typu instytucjach, ale także w bardziej skomplikowanych organizacjach, często ponadnarodowych (gospodarczych, społecznych, kulturowych), oraz zarządzaniem w różnej skali układów przestrzennych (lokalnych, regionalnych, krajowych) czy w układzie globalnym. Istotną w tym rolę odgrywają więc kryteria doboru odpowiednich osób do sprawowania określonych funkcji. Podstawowe znaczenie mają zasoby intelektualne poszczególnych jednostek oraz ich postawy przedsiębiorcze, które doskonalą się dzięki regułom konkurencji intelektualnej. Wyłączenie mechanizmu konkurencji intelektualnej, zwłaszcza z życia społecznego, powoduje często preferencje dla jednostek niezdolnych do wykonywania stawianych przed nimi zadań, co niekiedy uwidacznia się w życiu publicznym.

Generalnie w strukturze społecznej można wyróżnić szereg grup pracowniczych spełniających określone funkcje:

1. organizatorów produkcji, których reprezentują:

- przedsiębiorcy zarządzający swoją własnością (własnym kapitałem);

- menedżerowie zarządzający przedsiębiorstwami, instytucjami o różnych formach własności, wynajmowani (przez określone struktury własności) do wykonywania określonych zadań;

2. wykonawców działalności produkcyjnej lub usługowej:

- kierujących procesami technologicznymi na niższych szczeblach zarządzania;

- wykonujących polecone im zadania; 
3. rozwijających możliwości produkcyjne i organizacyjne:

- opracowujących i wdrażających nowe technologie i narzędzia pracy;

- opracowujących nowe, racjonalne formy zarządzania;

4. korzystających z efektów pracy produkcyjnej przez zarządzanie i uczestnictwo w usługowych sekcjach gospodarki, które mają bardzo ważne funkcje w zakresie podnoszenia jakości społeczeństwa, takich jak:

- ochrona zdrowia - dbałość o profilaktykę i zdrowie fizyczne i psychiczne poszczególnych osób i całego społeczeństwa;

- edukacja - przygotowywanie kadr na różnym poziomie wykształcenia, niezbędnych do rozwoju poszczególnych sektorów gospodarki, a tym samym podnoszących jakość społeczeństwa i zwiększanie jego zasobów intelektualnych;

- kultura - kształtowanie struktury duchowej i osobowości człowieka, a na tej podstawie - postaw przedsiębiorczości i odpowiedzialności moralnej za oferowane produkty.

Kształtując postawy przedsiębiorcze młodzieży, należy przyjać, że np. w konstrukcji budżetu występuje ścisła zależność między dochodami a wydatkami. Możliwe są trzy warianty:

- dochody równają się wydatkom,

- dochody są większe od wydatków, pozostają środki np. na inwestycje,

- dochody są mniejsze od wydatków, powstaje deficyt, który należy niwelować przez zaciąganie kredytów, co zwiększa dług publiczny.

Podział dochodów dokonywany jest na podstawie przyjętych kryteriów wyboru, które powinny uwzględniać stopień efektywności wydatkowanych pieniędzy lub racjonalność celów społecznych, które mają być realizowane.

Konieczne więc jest powszechne zrozumienie przez społeczeństwo oczywistej prawdy, że aby ustalać wydatki, należy zastanowić się nad źródłami dochodów. Mówienie tylko o większych wydatkach, np. dla określonych grup społecznych, najczęściej w czasie kampanii wyborczych, jest działalnością w znacznej mierze populistyczną. W społeczeństwie stwarza to postawy roszczeniowe, które są skutkiem braku wiedzy o możliwościach zwiększenia dochodów. Obejmujący władzę często muszą się wycofywać z takich obietnic.

Postawa przedsiębiorcza przejawia się natomiast określaniem możliwości zwiększenia dochodów (czy źródeł finansowania), podaniem racjonalnych kryteriów ich podziału (według przyjętych priorytetów, potrzeb), na których podstawie ustala się strukturę wydatków. Rozwijanie postaw przedsiębiorczych wpływa więc na pobudzanie w społeczeństwie działań na rzecz zwiększenia aktywności jednostek w zakresie możliwości zwiększania dochodów i w znacznym stopniu osłabia postawy roszczeniowe.

Dlatego - w nawiązaniu do współczesnych tendencji rozwoju społeczeństwa informacyjnego, którego kształtowanie opiera się na nowej bazie ekonomicznej, jaką są zasoby wiedzy - niezbędna wydaje się konieczność coraz powszechniejszej znajomości podstawowych reguł funkcjonowania gospodarki. Reguły te, oparte na powszechnie przyjmowanych zasadach etycznych, kształtują odpowiednie relacje między przedsiębiorczościa, gospodarką a społeczeństwem.

Podstawową rolę w tym zakresie odgrywa rynek pracy. Przyjmujemy, że spotykają się na nim pracodawca i pracobiorca, którzy kierują się odmiennymi, a często sprzecznymi interesami (ryc. 1). Z pewnym uproszczeniem można przyjać, że pracodawca dąży do minimalizacji płacy, a pracobiorca do jej maksymalizacji. Te zachowania w zależności od sytuacji na rynku pracy można rozpatrywać $\mathrm{w}$ trzech wariantach, a to w warunkach: niedoboru zasobów pracy, 
jej nadmiaru oraz równowagi. W poszczególnych wariantach zaznaczają się odmienne tendencje zachowań, które przejawiają się odpowiednio dążeniem do maksymalizacji płacy, jej minimalizacji lub równowagi.

Ryc. 1. Funkcjonowanie rynku pracy

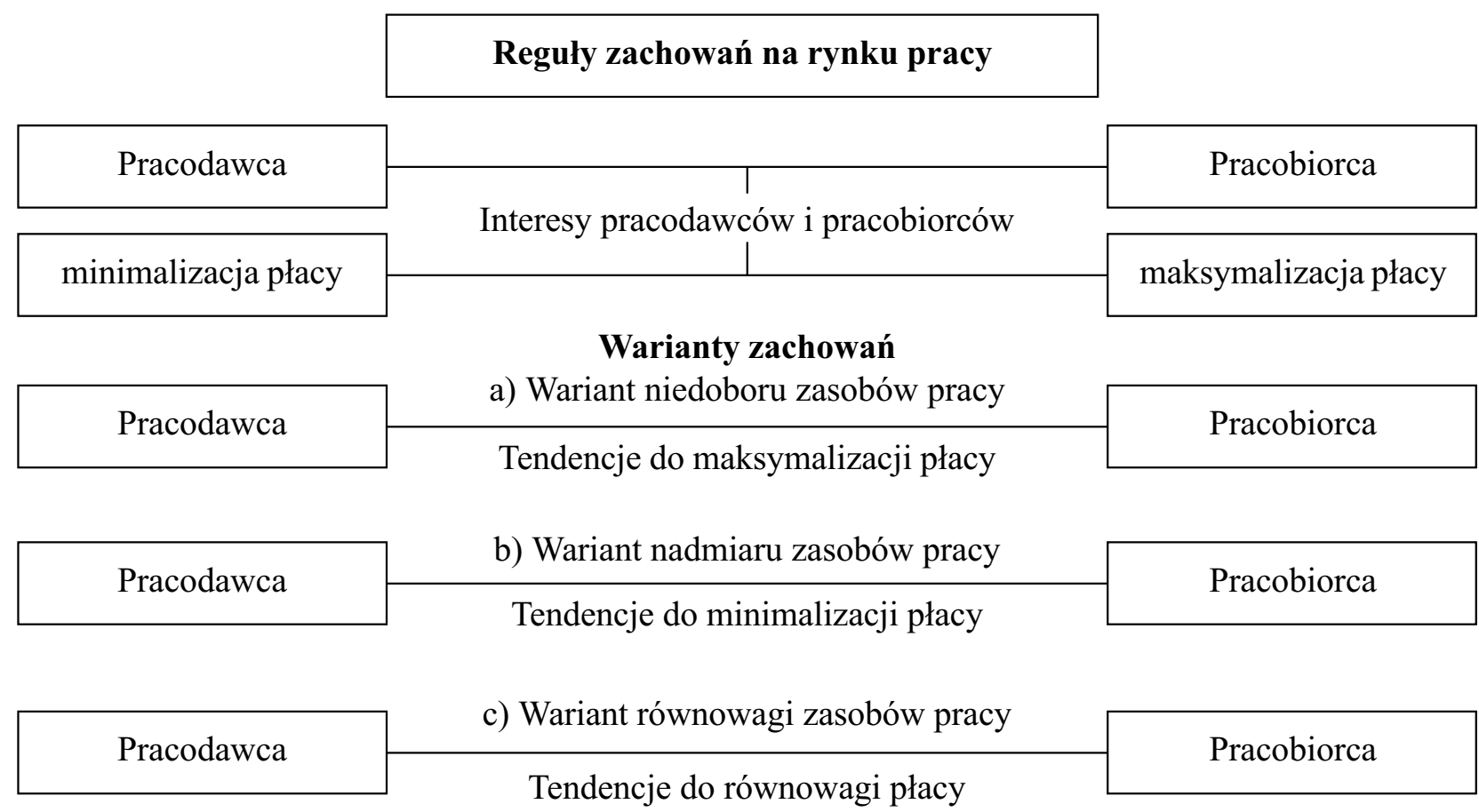

Ryc. 2. Relacje pracodawcy i pracobiorcy w procesie działalności przedsiębiorstwa

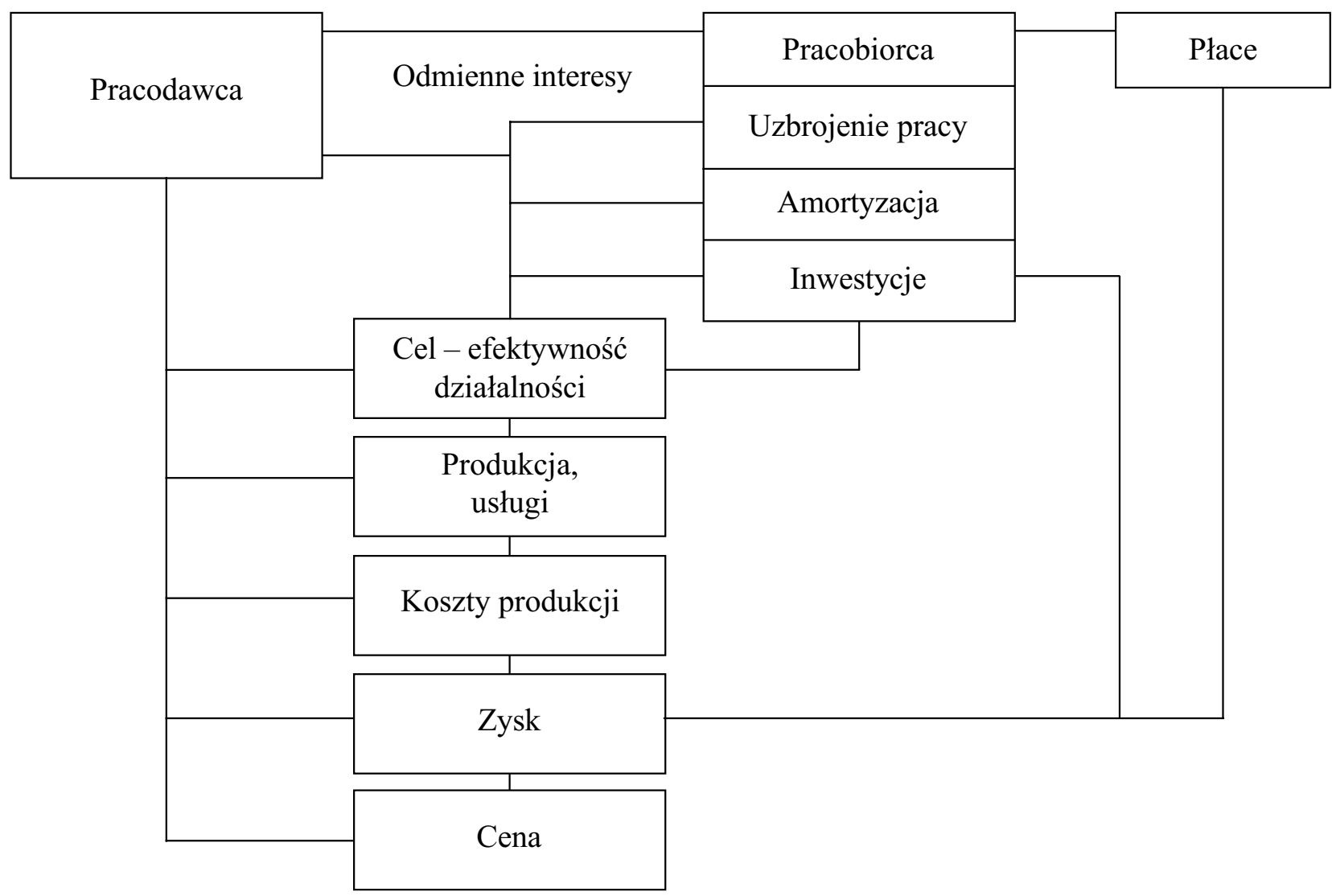


Bardziej złożony obraz przedstawia relacja pracodawca - pracobiorca w procesie działalności przedsiębiorstwa (ryc. 2). Z pewnym uproszczeniem można przyjąć, że podstawowe znaczenie ma tu cel pracodawcy, który zmierza do podnoszenia efektywności produkcji, ponosząc odpowiednie koszty i określając odpowiednią cenę. Warunkiem realizacji tego celu jest dbałość o odpowiednie uzbrojenie techniczne pracy oraz podejmowanie działalności inwestycyjnej z wypracowanego zysku. Odmienne interesy - przejawiające się niekiedy konfliktami społecznymi - uwidaczniają się w tym, że pracobiorca zainteresowany jest głównie maksymalizacją płacy, która wpływa na podział wypracowanych środków (zysku), ograniczając w ten sposób np. środki na inwestycje. W tej sytuacji widoczne są wyraźnie odmienne interesy pracodawcy i pracobiorcy.

Sprzeczne interesy pracodawcy i pracobiorcy można rozwiązywać, opierając się na zasadach etycznych, którymi kieruje się firma A (ryc. 3). W warunkach konkurencji na rynku między różnymi firmami zarówno pracodawca, jak i pracobiorca zdają sobie sprawę, że ich produkt, który jest efektem wspólnych działań, musi być konkurencyjny. Jeżeli nie będzie spełniał tego warunku, pracodawca utraci kapitał, a pracownicy utracą miejsca pracy. Ta sytuacja wymusza wspólne działania na rzecz podnoszenia pozycji konkurencyjnej oferowanych produktów. Obie strony, mające do tej pory odmienne interesy, integrują się i stawiają przed sobą wspólny cel - utrzymanie przedsiębiorstwa, głównie dzięki podniesieniu jego konkurencyjnej pozycji.

Ryc. 3. Miejsce etyki w warunkach konkurencyjnego zachowania przedsiębiorstwa

\section{Firma A}

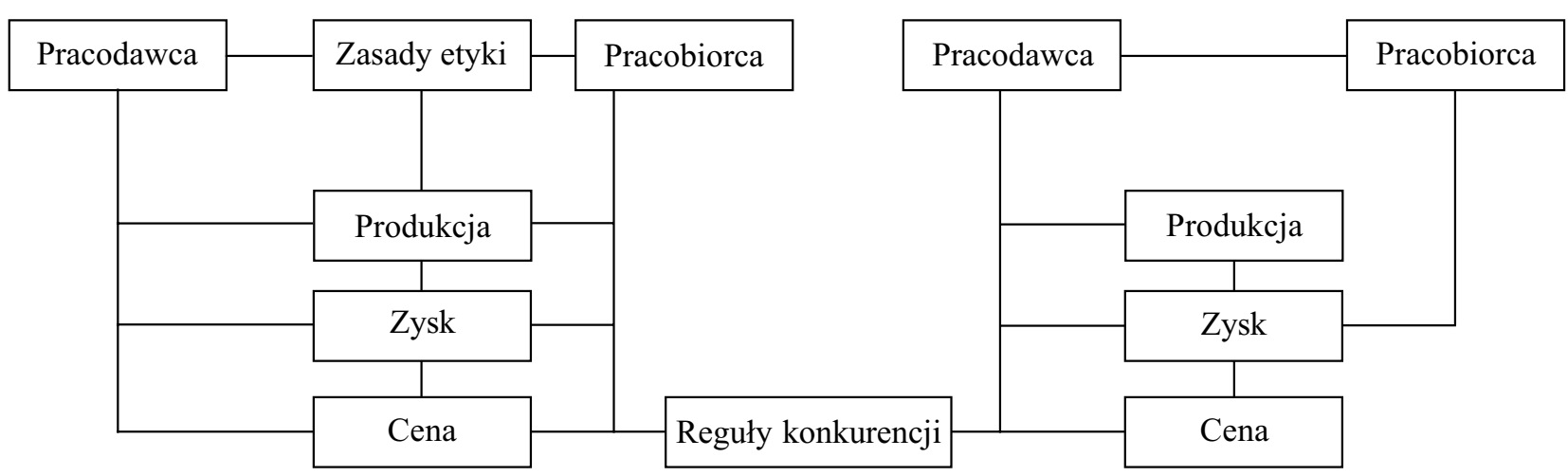

Zwiększanie konkurencyjności dzięki:

a) obniżeniu kosztów

b) podniesieniu jakości

c) obniżeniu kosztów, podnoszeniu jakości
Obniżanie kosztów dzięki:

a) obniżeniu kosztów pracy

b) obniżeniu wydatków na amortyzację

c) obniżeniu wydatków na inwestycje

d) obniżaniu innych wydatków

Przyjęcie zasad etyki uaktywnia nową jakość w funkcjonowaniu przedsiębiorstwa - dokonuje się integracja społeczna pracobiorców i pracodawcy przez włączenie ich w procesy produkcji i dążenie do zwiększania pozycji konkurencyjnej przedsiębiorstwa.

Zwiększenie konkurencyjności przedsiębiorstwa może się odbyć poprzez: obniżanie kosztów produkcji, podnoszenie jakości lub zarówno poprzez obniżenie kosztów, jak i podnoszenie jakości wyrobów.

Obniżanie kosztów produkcji generalnie może dokonywać się m.in. dzięki obniżeniu: kosztów pracy, wydatków na amortyzację, na inwestycje i innych. Obniżanie wydatków na amortyzację 
i na inwestycje prowadzi do zużycia technicznego maszyn i urządzeń oraz zmniejszania ich wydajności. Niewprowadzanie nowoczesnych urządzeń produkcyjnych jest przyczyną stopniowego starzenia np. parku maszynowego, co w konsekwencji obniża konkurencyjność przedsiębiorstwa. Obniżanie wydatków na płace powoduje zubożenie gospodarstw domowych pracowników, zmniejsza siłę nabywczą społeczeństwa i nasila działanie bariery popytowej. Towarzyszące temu sytuacje konfliktowe mogą prowadzić do przenoszenia działalności produkcyjnej na obszary o niższych kosztach pracy lub do upadku przedsiębiorstwa.

Koszt jednej godziny pracy w różnych krajach jest zróżnicowany i waha się od 0,39 dolara w Indonezji do 30,6 dolarów w Niemczech (w Polsce wynosi 2,7 dolara; tab. 1). Wysokie koszty pracy w Niemczech są przyczyną wyprowadzania wielu przedsiębiorstw do krajów o niższych kosztach pracy lub ograniczania dotychczasowych rozmiarów produkcji i zatrudnienia. Na przykład jesienią 2005 r. General Motors ogłosił, że w ciagu dwóch lat zwolni 12 tys. pracowników, czyli prawie $20 \%$ zatrudnionych w Europie ${ }^{4}$. Największe zwolnienia nastapią w Niemczech, gdzie pensje robotników sięgają 40 euro za godzinę; produkcja samochodów w tych warunkach koncernowi się nie opłaca.

Pod koniec 2004 r. w filii Mercedesa w Niemczech pracowało 94 tys. pracowników. Wobec pogarszającej się sytuacji na rynku samochodowym przewiduje się zwolnienie ponad 8 tys. pracowników, czyli ponad 10\% załogi. W 2005 r. koncern Daimler Chrysler, w którego skład wchodzi Mercedes, zobowiązał się nie stosować przymusowych zwolnień w fabrykach na terenie Niemiec, w zamian za co związkowcy zgodzili się na obniżkę płac, która do końca 2007 r. ma przynosić około 0,5 mld euro oszczędności rocznie. W obecnej sytuacji koncern nie chce wprowadzać zwolnień grupowych, lecz próbuje nakłaniać pracowników do rezygnacji z pracy w zamian za odszkodowanie. Odszkodowania wyniosą około $950 \mathrm{mln}$ euro, ale dzięki temu firma zachowa konkurencyjność na rynku ${ }^{5}$.

Znaczne różnice kosztów pracy skłaniają koncerny samochodowe do przenoszenia produkcji popularnych modeli samochodów do Europy Środkowej lub do Chin. Należy sądzić, że ten proces będzie się nasilał, ponieważ przy bardzo niskich kosztach pracy w Chinach $(0,80$ dolara za godzinę) żaden kraj europejski nie jest w stanie wytrzymać konkurencji. W Polsce w latach transformacji gospodarki narodowej ten sam mechanizm był przyczyną upadku wielu źle zarządzanych przedsiębiorstw ${ }^{6}$.

Przyjęcie zasad etyki uaktywnia nową jakość w funkcjonowaniu przedsiębiorstwa, dzięki czemu możliwa jest integracja społeczna pracodawcy i pracobiorców poprzez stawianie sobie wspólnego celu, jakim jest zwiększenie pozycji konkurencyjnej przedsiębiorstwa m.in. przez włączanie pracowników w procesy decyzyjne (firma A, ryc. 3). Do realizacji wspólnego celu często są niezbędne zmiany struktur organizacyjnych, dodatkowe nakłady na inwestycje, a niekiedy ograniczanie kosztów pracy. Nad racjonalnym przebiegiem tego procesu muszą czuwać odpowiednio przygotowany organ zarządzający oraz pracownicy o wykształconych postawach przedsiębiorczych lub ich przedstawiciele, zorganizowani np. w strukturach związków zawodowych. Znanych jest wiele przypadków przedsiębiorstw, w których pracownicy w celu utrzymania stanowisk pracy godzą się na wydłużanie czasu pracy i obniżanie płacy, rezygnują

\footnotetext{
${ }^{4}$ A. Kublik, Niemieckie koncerny motoryzacyjne likwiduja tysiace miejsc pracy, „Gazeta Wyborcza”, 2.10.2005 r.

${ }^{5}$ Mercedes zwolni ponad 8 tys. pracowników?, aktualizacja w portalu „Gazety Wyborczej”, 29.09.2005 r.

${ }^{6}$ T. Rachwał, Funkcjonowanie przedsiębiorstw przemystowych Polski Poludniowo-Wschodniej w procesie transformacji systemu gospodarowania, rozprawa doktorska, Kraków 2004.
} 
z wcześniejszych przywilejów (np. w koncernach Forda, GM). W takich warunkach pracobiorca zaczyna być traktowany ,nie jako narzędzie produkcji, ale jako sprawczy podmiot, a więc jako właściwy sprawca i twórca"”.

Tab. 1. Koszt godziny pracy w wybranych krajach w $2003 \mathrm{r}$.

\begin{tabular}{|c|c|c|c|c|}
\hline Kraje & $\begin{array}{c}\text { Koszt godziny pracy } \\
\text { (w dolarach) }\end{array}$ & Indonezja $=100$ & Niemcy $=100$ & Polska $=100$ \\
\hline Indonezja & 0,4 & 100,0 & 1,3 & 14,4 \\
\hline Chiny & 0,8 & 205,1 & 2,6 & 29,6 \\
\hline Indie & 1,1 & 287,2 & 3,7 & 41,5 \\
\hline Rosja & 1,5 & 384,6 & 4,9 & 55,6 \\
\hline Tajlandia & 2,0 & 502,6 & 6,4 & 72,6 \\
\hline Malezja & 2,1 & 535,9 & 6,8 & 77,4 \\
\hline Meksyk & 2,5 & 628,2 & 8,0 & 90,7 \\
\hline Polska & 2,7 & 692,3 & 8,8 & 100,0 \\
\hline Brazylia & 2,8 & 705,1 & 9,0 & 101,9 \\
\hline Węgry & 3,5 & 905,1 & 11,5 & 130,7 \\
\hline Czechy & 3,6 & 933,3 & 11,9 & 134,8 \\
\hline Tajwan & 5,7 & 1453,8 & 18,5 & 210,0 \\
\hline Korea & 10,0 & 2561,5 & 32,6 & 370,0 \\
\hline Hiszpania & 12,3 & 3159,0 & 40,3 & 456,3 \\
\hline Włochy & 16,6 & 4246,2 & 54,1 & 613,3 \\
\hline Francja & 17,8 & 4556,4 & 58,1 & 658,1 \\
\hline Wielka Brytania & 17,9 & 4582,1 & 58,4 & 661,9 \\
\hline Kanada & 18,4 & 4728,2 & 60,3 & 683,0 \\
\hline Japonia & 20,7 & 5302,6 & 67,6 & 765,9 \\
\hline Stany Zjednoczone & 21,9 & 5605,1 & 71,4 & 809,6 \\
\hline Niemcy & 30,6 & 7846,2 & 100,0 & 1133,3 \\
\hline
\end{tabular}

Uwaga. W koszt pracy wliczono wszystkie obciążenia, jakie ponosi pracodawca.

Źródło: za „Gazetą Wyborczą”, 23.06.2004 r.

${ }^{7}$ Jan Paweł II, Encyklika O pracy ludzkiej, reprint Libreria editrice vaticana, TUM, Wrocław 1995, s. 25. Również w homilii do górników w Legnicy, 2.06.1996 r. Papież stwierdził: „Praca ludzka nie może być traktowana tylko jako siła robocza. Człowiek nie może być widziany jako narzędzie produkcji. Celem pracy, każdej pracy, jest sam człowiek". 
Odmienne uwarunkowania funkcjonowania przedsiębiorstwa występują w firmie B (ryc. 3), gdzie w jego działalności nie uwzględnione są zasady etyki. W takich warunkach pracobiorcy są wyłączeni z procesu zarządzania firmą i uwidacznia się odmienność interesów pracodawców i pracowników. Praca jest traktowana jak towar; obok zespołu narzędzi i środków sprzedaje się ją pracodawcy po możliwie najwyższej cenie. Konkurowanie między firmami tych dwóch kategorii (A i B) wpływa na dalszą integrację społeczną opartą na zasadach etyki w firmie A i nasilanie się potencjalnych konfliktów w firmie B.

Można więc przyjąć, że wykształcone u pracodawców i pracobiorców postawy przedsiębiorczości umożliwiają szybsze wdrażanie zasad etycznych w przedsiębiorstwie, a także w stosunkach gospodarczych i społecznych. Uniemożliwia to degradację człowieka jako przedmiotu pracy, połączoną często z dużym wyzyskiem płacowym i nieodpowiednimi warunkami pracy, zwiększa także troskę o osobę pracownika. Stwarza to warunki do wzmacniania identyfikacji pracownika z firmą, dzięki czemu dba on o rozwój firmy, doskonaląc swoje umiejętności i wprowadzając zmiany, których celem jest podniesienie konkurencyjności produktu firmy na rynku.

W ten sposób realizuje się podstawowa zasada etyczna, że pierwszą podstawową wartością pracy jest sam człowiek, a zatem praca jest dla człowieka, nie zaś człowiek dla pracy. Oznacza to, że praca ludzka jest kluczem do realizacji całej kwestii społecznej ${ }^{8}$. Generowane w konkurencyjnych przedsiębiorstwach środki finansowe, płynące do gospodarstw domowych, w zasadniczym stopniu warunkują bowiem podnoszenie jakości życia rodziny, wzrost gospodarczy i rozwój społeczny układów lokalnych, regionalnych, gospodarki krajowej, a także gospodarki bardziej złożonych struktur, np. Unii Europejskiej.

Reasumując, dotychczasowy proces rozwoju społecznego dokonywał się dzięki systematycznemu rozwojowi myśli człowieka, dzięki której mógł on wytwarzać coraz bardziej złożone produkty, systematycznie doskonalić narzędzia pracy i tworzyć coraz lepiej zorganizowane systemy zarządzania. Proces ten nasili się w najbliższej przyszłości, w warunkach informacyjnej fazy rozwoju, w której coraz większego znaczenia będą nabierać nowe kwalifikacje i umiejętności pracowników, pozwalające na coraz sprawniejsze uczestnictwo człowieka w nowoczesnych procesach zarządzania, produkcji, gospodarowania i organizowania społeczeństwa. Wydaje się, że tym nowym wyzwaniom jest w stanie sprostać tylko człowiek odpowiednio przygotowany: wyposażony w umiejętność działania, dysponujący rozwiniętymi cechami przedsiębiorczości i wrażliwością etyczną.

\section{The Part Entrepreneurship Plays in Increasing the Competitiveness of Society and Economy}

The goal of this article is to present what role human capital and attitudes of entrepreneurial persons play in increasing the competitive power of economy, when informational civilization develops. Role of a man and his ethical choices during social and economic growth and development of corporations, is emphasize in this work.

\footnotetext{
${ }^{8}$ Jan Paweł II, Encyklika O pracy ludzkiej (Laborem excercens), op. cit.
} 